\title{
Louis MacNeice: Transmitting Horace
}

\author{
Alan J. Peacock \\ University of Ulster
}

Louis MacNeice's engagement with the work of Horace was a life-long affair. Even as a schoolboy he had admired the Roman poet's verbal succinctness ${ }^{1}$ and in his last years, with a deepening sense of kinship, he turned to him in meditative fellow-feeling in the poem "Memoranda to Horace" which apostrophises the Roman poet across the centuries, to sound areas of shared values and experience - as well as points of difference. Horace was a natural candidate for translation, given MacNeice's academic competence as a classicist, and he did in fact produce a handful of Horatian versions to supplement the extensive indebtedness which can be discerned in the allusive and thematic content of his poems throughout his career. It is this translating activity which is examined in what follows, rather than the more generalised debt: the exercises where MacNeice, following the humanistic tradition, acts as a transmitter of the achievements of the ancient world by means of direct translation. MacNeice, of course, was also professionally involved in another kind of "transmission" - the production of radio programmes which comprised MacNeice's full-time professional career from 1941-61, after his resignation from academic life.

In particular, one broadcast, Carpe Diem, put out on October 8 th $, 1956,{ }^{2}$ is a fulcral item in MacNeice's activity as a translator of Horace. Much of the programme consists of straight prose translation of Horatian tags and excerpts by the protagonist of this dramatic feature; and within this dramatic construct, which is an exposition of Horace's qualities and continuing relevance, there are included actual translations of Horatian poems by MacNeice and others. As such, it provides an invaluable lead-in to the whole question of MacNeice's practice and achievement as a translator of Horace - firstly because of the material which it contains in terms of actual translation; but also because of the various kinds of translation which it features, not all of which find their way into MacNeice's formal literary corpus. For within the more occasional, ephemeral context of a radiobroadcast, MacNeice experiments with forms of exposition, paraphrase and translation which are excluded from his more "literary" productions, but which dove-tail revealingly with them. It is this latter quality which is taken up here in connection with MacNeice's translations elsewhere, rather than the specific merits of the piece as a radio programme. 
Carpe Diem takes the form of a dialogue between Quintus and Elaine, an elderly couple of the present day (the date, it transpires, is the date of the transmission). He, ill in bed and awaiting the doctor, reviews his life - his recollections triggered by snatches of music (light opera, popular songs, jazz) which his wife plays for him on the gramophone. His memories, however, hinge centrally on a seemingly endless sequence of Horatian tags and quotations, together with passages from English poets which translate Horace or are influenced by his work. The playlet is in fact a demonstration of the truth of the announcer's dictum in introducing the programme that Englishmen have "found in his (Horace's) works tags for nearly every occasion."

Schooled in his enthusiasm by his father, Quintus owes even his name to Horace (Quintus Horatius Flaccus) since "He had tags of Horace for everything, so I was tagged too at my christening." Horatian enthusiasm had not faltered at the anomaly of naming an only child "Fifth."

Like Horace, Quintus' father had shown a tendency to retreat from the contemporary world of luxury and acquisitiveness and had "bought his Sabine Farm in the Constable country":

\section{QUINTUS: .. "Fastidiosam," my father used to say, "Fastidiosam desere copiam"- \\ ELAINE: My dear, you know I don't know Latin.}

QUINTUS: Fastidiosam - he put me on to Horace when I was ten - Fastidiosam arrogant; desere - desert; copiam - luxury; abandon arrogant luxury: et and; molem - a mass, a pile - the buildings of London, of Rome, he means; propinquam - near to; nubibus - clouds; arduis - the lofty clouds; omitte - omit; mirari - to admire; beatae - of wealthy; fumum - smoke, smog; et opes - and riches; strepitumque - and din; Romae - of Rome.

Say goodbye to arrogant luxury and to the towering buildings that reach the clouds and cease to admire the smoke and the riches and the racket of wealthy London.

In this way, like a schoolmaster construing Horace for a class, MacNeice makes the obvious pedagogic connections between "then" and "now," and Horace's "smoke" becomes "smog" - a major London preoccupation of the 'fifties. Rome and London tend to become interchangeable.

The insistence here on ad verbum attention to a Latin text is interesting in its ambitious audience-demands. There is a determined attempt to demonstrate for the non-specialist how the sense of a passage by Horace discloses itself word-by-word on the page; and at the same time how at the heart of any such exercise in translation, as its motivating impulse, is a sense of the commonalty of human experience - a fellow-feeling which shrinks the intervening centuries. Quintus, for instance, like Horace had his fingers burned early in love by his "Pyrrha" ("her real name was Maude"), and hence the famous opening of Odes 1,5 is duly recalled: 
grato, Pyrrha, sub antro?

cui flavam religas comam

simplex munditiis?

Quintus makes the connection, but the tension between then and now, between the literary paradigm and the experiential reality, is also released in his glossing of this:

What handsome knut, spelt with a $\mathrm{K}$, embraces you now, my Pyrrha, my Maude? Simplex munditiis - with a simple line, no nonsense. There's a translation of it by Milton, you know. What slender youth bedewed with liquid odours? - that's Gilbert the Filbert of course -

Contemporary conversational idiom ("a simple line, no nonsense") and cultural experience (the song "Gilbert the Filbert" from The Passing Show) jostle in Quintus' consciousness with the Horatian datum. By contrast, Milton's version is read -

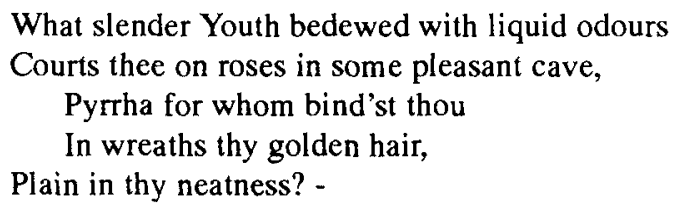

and saluted:

Much better than most translations. If only because of the word-order. "Who always vacant, always amiable, hopes thee." Keeping the hopes to the end is much more dramatic, you see. And here Milton's following Horace. Though of course it's much easier in an inflected language.

Here again, MacNeice the schoolmaster surfaces with the standard comments. More interesting, though, is how associative elements infiltrate Quintus' response to the Latin - how a simultaneous sense of affinity and inevitable cultural difference has triggered the racy up-dating in his version.

In any attempt to come to terms with the Classics, to make them continue as live elements in our culture, larger, conventional cultural analogies will be confirmed, or qualified, by more personal associations and correspondences which must, if the integrity of the experience is to be suggested, find some kind of articulation. Quintus' personal response is of this sort, personal, autobiographical: the modern world is reassuringly measured against classically authenticated exampla of human experience.

Similarly, when "Alexander's Ragtime Band" is played on the gramophone, "the first true example of jazz" as Quintus observes, it immediately sets off a stream of association. "It had only just crossed the Atlantic; that was early Nineteen Twelve." The year in fact of the Titanic disaster; and this in turn brings into play the ancient topos concerning the folly and presumption of man's venturing on the seas - and, in particular, a remembered 
stanza from Horace, Odes 1,3. As the stanza is presented in the broad-cast, each line is followed by the newsboys' shout: "Loss of the Titanic":

Loss of the Titanic! nequiquam deus abscidit

Loss of the Titanic!

prudens Oceano dissociabili

Loss of the Titanic!

terras, si tamen impiae

Loss of the Titanic

non tangenda rates transiliunt vada.

Good,professional radio-broadcast technique, it might be observed, making telling use of sound; and Quintus in good pedagogic fashion draws the obvious moral:

Yes, the Unsinkable Ship - the old Greek idea of hubris. Many of the preachers the next Sunday took Horace's view about it.

In a way analogous however to the invasive and enlivening modern and individually associative elements infiltrating versions of the Classics, MacNeice's routine broad-casting didacticism is subject to personal association. For the trigger for this section of the broadcast is to be found in MacNeice's early background in Carrickfergus (always within sight of the shipyard gantries) in a way which is made wryly explicit:

And I remember talking in the Nineteen-Thirties to one of the young writers of the time - was it Day-Lewis? no, MacNeice - and he told me that in the town where his father was rector, some little place in Northern Ireland, one of the locals - a fisherman perhaps, wrote a doggerel broadsheet on the subject. Inpiae rates ... the wicked presumptuous ships provoking heaven to punish them.

Remarkably, now, an Ulster brogue dove-tails with Horace's Latin:

ULSTER VOICE: LATIN READER: ULSTER VOICE: LATIN READER: ULSTER VOICE: LATIN READER: ULSTER VOICE: LATIN READER:
Men they have been proudly boasting -

Nil mortalibus ardui est;

Of building ships which cannot wrong; caelum ipsum petimus stultitia, neque

To me it seems as much disgusting per nostrum patimur scelus As snail to reindeer say "Come on!" iracunda lovem ponere fulmina.

MacNeice's responses to Odes 1,3 are as intimately bound up with the traditions and folklore of the Belfast Lough of his early years as Quintus' to Odes 1,5 are with memories of Maude and Gilbert the Filbert. The yoking of the anonymous Ulster doggerelist with Horace and his formal propemptikon for Virgil setting out for Greece makes a strange 
conjunction. In a slow-motion way, within the chore of putting together a broad-casting script, we can see a demonstration of the irrepressible associative processes which may animate any imaginative act of translation or literary analogising - and which need to be marshalled for aesthetic gain. The coy joke about attribution above indicates a certain wry embarrassment on MacNeice's part at the introduction of this rather anomalous Northern Irish perspective into Quintus' historical and autobiographical musings.

In fact, a major focus of interest in Carpe Diem resides in the way in which MacNeice's penetrating, individual and complex considerations of Horace supplant at times the more routine sentiments for which the conventional Quintus is made a mouthpiece. At one level, MacNeice is engaged in his professional job of putting together a radio programme. Horace however is a subject close to the centre of his artistic outlook, and hence dramatised lessons on the modern relevance of the Roman poet give way to a more declarative sense of empathy and fellow-feeling.

Quintus, who has lived through two world wars, fighting himself in the first and losing a son in the second, is, on one level a suitable vehicle for the kind of measured patriotism for which Horace is rich in motifs. Armistice day can be remembered with a comfortable conflation of Horace and Sassoon:

And for that day, and a little after, I really felt like the poem by Captain Sassoon: "Everyone suddenly burst out singing."

LATIN READER: $\quad$ Nunc est bibendum, nunc pede libero pulsanda tellus...

QUINTUS: $\quad$ Drink and dance! Cleopatra has been defeated. Bring out the vintage Caecuban. Look, Nelson is dancing too on top of his column.

These cultural collocations however touch on areas of resonating concern, and simplistic perspectives on conflict cede to a more qualified retrospect. Even in Quintus' scheme of values Horace has to be cited with discrimination:

I went out to the Front in 1915; and for once my father didn't quote Horace at me. Above all not the dulce et decorum bit - pro patria mori. Too many of my friends had died already. At Ypres in particular.

Rather, Horace's plangent dirge for Quintilius is cited at this point: "Quis desiderio sit pudor aut modus/tam cari capitis?" In Quintus' familiar terms of explication:

Quis - what: desiderio - to longing, regret, to grief: sit - should there be: pudor shame, restraint: aut modus - or limit: tam cari capitis - for such dear head, a dear person? 
Quintus is tapping a recognized elegiac vein in twentieth century attitudes to war - a dominant one in fact in the modern tradition of war poetry. Still following Horace, he dilates on the theme of human waste:

$\begin{array}{ll}\text { LATIN READER: } & \text { Ergo Quintilium perpetuus sopor urget? } \\ \text { QUINTUS: } & \begin{array}{l}\text { Does then eternal sleep press heavy } \\ \text { on Quintilius? Quintilius, Howard, }\end{array} \\ & \text { David, Hamish, Peter, Tom - }\end{array}$

Interestingly, Quintus' insistent, measured, word-by-word elucidation of the sense of Horace becomes, over and above its explicatory value, a moving kind of litany which reaches a concentrated peak in:

$\begin{array}{ll}\text { LATIN READER: } & \text { Multis ille bonis flebilis occidit. } \\ \text { QUINTUS: } & \text { By many he good people weepable fell. }\end{array}$

In a strange way, comparable with Pound's use of translationese in Homage to Sextus Propertius, the literal version, faithfully following the Latin word-order, takes on an emotive emphasis as the sense filters slowly through the strange-sounding formulation. MacNeice, almost by accident, here is using radical techniques which are not evident in his published verse-translations.

There is a coincidence between Quintus' routine ad verbum translating-habits and an area of deep concern and identification for MacNeice. The phrase "tam cari capitis" had aiready provided the title of a poem in Holes in the Sky (Poems 1944-47) - a lament for a dead friend (Graham Shepard), just as "age iam meorum finis amorum ..." another phrase used by Quintus, provides the epigraph for Solstices (1959). Behind the broad conventionalities of the broadcast, more urgent issues are pressing through: MacNeice, so to speak, the poet takes over momentarily from MacNeice the programme-maker with his more simplified formulae. (It is no doubt the case that the inevitable exchange in the other direction has something to do with the well-known dilution of MacNeice's concentrated lyric powers in his war-time and post-war poetry.)

It is a truism that the ancient tradition of poetry lives for us now, as it has done through successive periods of English Literature, by means of translation - not simply in the practical sense of the necessary provision of cribs to facilitate reading of original texts, but in the production of new texts which creatively re-interpret the Classics in the light of modern experience (the two initiatives can of course, ideally, run together). There is however a constant tension, in translations from the Latin, between the resources of an inflected and an uninflected language. The workaday renditions of Quintus illustrate the awkwardness which fidelity to Latin word-order can generate; while the suggestiveness of "By many he good people weepable fell" brings alive the strikingly suggestive possibilities for the poetic exploitation of precisely these same effects.

MacNeice the programme-maker makes routine use of the former in the low-level didacticism of Quintus; MacNeice the poet however is naturally more concerned with communicating the experience of reading Horace in more complex terms. He does this 
regularly elsewhere (in his published volumes) by thematic appropriation and development and, occasionally, by conventional Anglicising translations. In this context however he is able to develop Quintus' schoolmasterly habits into a translating technique which exploits the possibilities of ad verbum idiom and word-order. Odes I, 11, from which the programme derives its "Carpe Diem" title is rendered as follows:
Ask not - it is forbidden to know - what for you or for me
End is appointed, Leuconoe; shun the astrologers,
Leave the palmists alone. Much better endure what shall be;
Whether more winters are ours or this be the last
Which now on the ramparts of rock is exhausting the battering
Waves. So be canny, bottle your wine; life is short and unequal,
Shorten your long-drawn hopes. Envious time, even while we are chattering,
Steals a march on us. Capture the minute, trusting the least to the sequel.

Compare:

Tu ne quaesieris - scire nefas - quem mihi quem tibi

finem di dederint, Leuconoe, nec Babylonios

temptaris numeros ...

Here Quintus' pedagogic method is transformed into creative technique. We have a new poem which initially, but then more interruptedly, preserves the word-order of the original, and then skirts close to "translationese" -but which also, by the same token, generates its own slightly strange manner and rhetoric. "Ask not - it is forbidden to know, what for you or for me / end is appointed" or "Capture the minute, trusting the least to the sequel" are not normal, or even poetic, English usage. They do however have an undeniably distinctive quality to them - terse, oracular and a little alien.

Interestingly, however, as the poem proceeds it takes more liberties, eliding words in the Latin text and even admitting adventitious associative detail. The, injunction to "leave the palmists alone," for instance, although a reasonable filling out of the sense of the astrological reference in the Latin to "Babylonian numbers," is in fact a spill-over from Quintus' anecdote about the First World War, where a palmist could read nothing beyond a few months on the young men's life-lines.

MacNeice's published version of this ode, done a few years later, significantly preserves a more consistent decorum of English idiom:

Do not, Leuconoe, seek to inquire what is forbidden, what

End the gods have assigned to you or to me; nor do you meddle with

Astrological numbers. What shall arise count to your balance if

God marks down to you more winters - or perhaps this very one is the

Last which now on the rocks wears out the fierce Mediterranean

Sea; but be wise and have wine, wine on the board, prune to a minimum

Long-drawn hopes. While we chat, envious time threatens to give us the

Slip; so gather the day, never an inch trusting futurity. ${ }^{3}$ 
No doubt this is, in a sense, more "satisfactory" as E. R. Dodds notes. ${ }^{4}$ It stays close to the Latin, but avoids as far as possible the bizarre effects associated with "translationese." It has, however, perhaps lost something of the sense in the first version, of the "otherness" of the original.

With the line "By many he good people weepable fell" MacNeice achieved, as was seen, a strangely affective sort of emphasis in his extreme literalism. Though verging on nonsense, the line, which forces us to read it slowly word by word, generates a special kind of weight and seriousness. For a fully worked out creative exploitation of the possibilities of this technique Pound's Homage to Sextus Propertius of course provides the model. An ad verbum scan-reading response to the Latin text generates the following kind of version:

Though my house is not propped up by Taenarian columns

from Laconia (associated with Neptune and Cerberus),

Though it is not stretched upon gilded beams;

My orchards do not lie level and wide as the forests

of Phaeacia the luxurious and Ionian,

Nor are my caverns stuffed stiff with a Marcian vintage,

My cellar does not date from Numa Pompilius,

Nor bristle with wine jars,

No is it equipped with a frigidaire patent;

Yet the companions of the Muses will keep their collective nose in my books, And weary with historical data, they will turn to my dance tune. ${ }^{5}$

It is this kind of passage, surreally distorting the sense of the Latin, which has led, at times, to critical scorn at the "howlers" involved. This is not however the substantive issue.

Pound in fact exploits poetically the intermediate phase between reading a poem in Latin and simultaneously translating it either mentally or on the page - and the subsequent re-structuring of it in English idiom to provide what we normally mean by a formal translation. Of course, where the source language is not "second nature" to the translator as in Pound's shaky (by comparison with MacNeice) relation to Latin, the process will also involve distortions and misapprehensions, and it is his inclusion of these which constitutes the radicalism of his technique in the Homage. In a less extreme way therefore, in the Carpe Diem broadcast, MacNeice in his version of "Tu ne quaesieris ..." offers a kind of translation which, like Pound's, is closer to the intermediate phase. The resulting "Poundianisms" however are more rigorously eliminated from the published version. Hence the special interest of the broadcast which, via the dramatised translating-habits of Quintus, allows scope for introducing such effects in both casual and more formal terms.

In propria persona, MacNeice does not characteristically allow himself this licence; at the verbal level in his formal translations he tends to adhere to traditional neo-classical decorum. The anarchic play of verbal and thematic association is more carefully regulated. The endemic tensions however are not eliminated. There can never be an uncomplicated transfer from the particularities of one language to another; and similarly, at the temperamental level, whatever the degree of identification between translator and original, there will always be disparities. As Quintus observes, "Horatian philosophy" does not 
always "quite fit the bill." On the other hand, in a way which MacNeice poignantly explores in his late poem "Memoranda to Horace," a sense of intellectual kinship can, remarkably, be felt between one poet and another even across two intervening millennia; and the special nature of this sense of identification is all the more valued in the light of the inevitable discontinuities and disjunctions:

So what have we, Flaccus, in common? If I never

Boasted a Maecenas, you never summarised

Life from Rockefeller Centre

And if you never moved in a Christian framework

I never moved in a pagan...

It looks as if both of us

Met in the uniqueness of history a premise

That keeps us apart yet parallel,

The gap reducible only by language. ${ }^{6}$

Translation seeks to bridge that gap by sympathetic re-creation, but the sense of difference or distance is also a necessary conditioning factor; and the kind of product which can result, enshrining that tension, is seen in the version, in the Carpe Diem broadcast, of Odes 2,3:

A level mind in crooked times

Preserve, preserve; nor in better fortune

Dash into rash self-glory,

My brother bound for death -

Whether your life be a string of doldrums

Or whether you loll on days of festa

At a private fete champetre

With a bottle of vintage wine ...

Compare:

Aequam memento rebus in arduis servare mentem, non secus in bonis

ab insolenti temperatam laetitia, moriture Delli,

seu maestus omni tempore vixeris, seu te in remoto gramine per dies

festos reclinatum bearis interiore nota Falerni.? 
"Crooked times" and the idea of life as a "string of doldrums" do not quite accurately render Horace's "rebus in arduis ("in difficult circumstances") and reference to life's sadness ("maestus"). MacNeice is obviously at one level commenting on his own experience of "low, dishonest" decades and the sense of nullity which afflicted him intermittently from his early years on. He is assimilating Horace into his own experience in these touches, though generally in the poem the Latin is respected, as also is the Alcaic stanzaic patterning.

Horace's message of resignation in the face of human mortality is rendered in language which asserts its relevance to here and now - colloquial, civilized and un-stilted. MacNeice translates primarily as a modern poet concerned to write for his own time; but also as an (ideal?) classicist: alert to the verbal nuances of the original and its metrical form, but avoiding the all-too-common archaizing in translations by classicists:

Towering pine and silver poplar -

Why do they intermingle their friendly

Shade? And why do these cantering waters

Jockey their way through winding banks?

Here is the place for wine and perfume

And the too fleeting bloom of the rose

While Time and Chance and the black threads

Of the three Fates give chance and time.

This is a good instance of the kind of creative accommodation which MacNeice is able to make, in his translations and elsewhere, between the ancient world and the world of everyday modern experience.

In his translations, MacNeice shows the same intelligent, unsentimental, analytical response to the past as he does, say, in the well-known sections on Greek civilization in Autumn Journal. The ancient world is not allowed to petrify in a series of frozen, sanctified attitudes. As scholar, poet, translator and broadcaster MacNeice is aware that the vital continuity of tradition is dependent on a due mixture of piety and imaginative recreation. Verbally haunted by the Latin poet, as for example the rash of Horatian reminiscences in "Memoranda to Horace" demonstrates, and subscribing in his attitude to life to something not very different from Horace's "Middle Way," he is nevertheless in some ways a more astringent commentator on human experience; and the verbal reminiscences can take on a significant sea-change in particular contexts. For instance, "Lusisti satis," a phrase used in "Memoranda to Horace" as a familiar Horatian tag, is also to be found in Carpe Diem. But Horace's modulated injunction in Epistles 2,2 to accept the waning of one's power's and, in due course one's life, and to say farewell now to lyric poetry, is given a sharp no-nonsense application by Quintus:

Lusisi satis, edisti satis atque bibisti - You have played enough, you have eaten enough and drunk enough - That's what you mean, isn't it? Tempus abire tibi est - It is time for you to depart... 
In an even more subtle way, Quintus' comment on Milton's suspension of meaning through the reproduction of Horace's word-order in "What slender youth ..." (quoted above) -

Much better than most translations. If only because of the word-order. "Who always vacant, always amiable, hopes thee." Keeping the hopes to the end is more dramatic, you see. -

is poignantly recalled in an associative way later in the broadcast, as we have become more aware of Quintus' debility:

\author{
I know I'm living in bed, but I don't \\ want to die in the past... \\ Grata superveniet quae non sperabitur \\ hora. Keeping the hopes to the end... \\ How many months to Spring, my dear?
}

It is not clear exactly whether Quintus the character or MacNeice the writer is subject to this verbal suggestiveness, as a phrase out of the half- or sub-conscious is reapplied in a new context. Probably, the truth is that the distinction has ceased to apply in any hard-andfast way, and that Quintus has become a vent for some of MacNeice's own concerns and associative mental processes. Quintus ends, firing off Horatian tags in a jumbled reprise of all that have surfaced in the play so far - and MacNeice is still turning them over and over in "Memoranda to Horace" years later.

Carpe Diem in its unstable, unpredictable utilizations of Horatian material, and its spectrum of translation-techniques ranging from raw, ad verbum construing to fully realized English versions provides an invaluable insight into the second-nature familiarity of MacNeice's awareness of the Classics - an element in his intellectual make-up which is often underestimated in commentary on his outlook and affiliations. To Ireland and England as cultural territories laying claim to his awareness and intellectual allegiance must always be added Greece and Rome. More than this, however, the programme demonstrates the inventiveness and radicalism, the experimentalism which, within the loosely structured format of a dramatic feature, MacNeice was able to relax into. The Titanic, Ulster doggerel and Carrickfergus rub shoulders with Horace and Rome; the First and Second World Wars collapse associatively into Rome's martial experience; and, remarkably, Horace at one point can provide the jumping-off ground for a rejection of the atomic bomb!

\title{
Notes
}

1. Cf. Louis MacNeice, Modern Poetry, 2nd. ed. (Oxford: Clarendon Press, 1968), p. 49: "As a boy I liked the glitter of Horace - $O$ fons Bandusiae splendidior vitro - and admired his tidiness, realizing that English with its articles and lack of inflexions could hardly ever equal Horace either in concentration or in subtlety of word order." 
2. Carpe Diem, written and produced by Louis MacNeice, Third Programme, Monday, 8th October $1956,7.30-8.15$ p. m.

3. Louis MacNeice, Collected Poems, ed. E.R. Dodds (London: Faber, 1966), p. 550.

4. Ibid.

5. Personae: Collected Shorter Poems of Ezra Pound (London: Faber, 1952), pp. 218-19.

6. Collected Poems, pp. 540-41.

7. Horace, Odes, ed. T. E. Page (London: Macmillan, 1964), p. 40. 